\title{
Towards Responsible Business Conduct in Global Value Chains
}

\author{
Relevant Legal Developments in the Netherlands
}

\author{
Liesbeth Enneking \& Jeroen Veldman*
}

\begin{abstract}
The past few decades have seen an increasing scrutiny of the impacts - both positive and negative - that companies have on the societies in which they operate. The search for adequate responses to such scrutiny is reflected in developments in the societal, political and academic debate on three separate but interrelated concepts: corporate social responsibility, business and human rights and responsible business conduct. The focus in this Special Issue will be on law and policy relating to responsible business conduct in global value chains. The contributions in this Special Issue identify relevant developments and institutions in the Netherlands, including rules and regulations related to trade, investment and corporate governance as well as cases related to corporate and consumer responsibilities, and assess their role in relation to the potential to provide a positive response to the concern about the human and environmental impacts of business activities. Together, they provide a multi-perspective view of relevant gaps and/or best practices with regard to regulatory governance in the Netherlands while at the same time enabling a comparative debate on the extent to which these diverse developments and institutions are in line with stated policy goals in this context both at national and EU levels. In doing so, this Special Issue aims to contribute to further coherence between national and EU policies with regard to RBC in global value chains and sustainable development.
\end{abstract}

Keywords: responsible business conduct, business and human rights, corporate social responsibility, sustainable development, the Netherlands

\section{Introduction of the Topic}

The past few decades have seen an increasing scrutiny of the impacts - both positive and negative - that companies have on the societies in which they operate. A

\footnotetext{
Liesbeth Enneking is Professor of Legal Aspects of International Corporate Social Responsibility at Erasmus School of Law, Erasmus University Rotterdam. Jeroen Veldman is Visiting Associate Professor at Rotterdam School of Management, Erasmus University Rotterdam, Visiting Associate Professor at Mines Paristech, Interdisciplinary Institute for Innovation, Paris and Section Editor Corporate Governance at the Journal of Business Ethics.
}

broad debate is ongoing, in which a wide variety of societal actors, including for example industry bodies (like the WEF, ${ }^{1} \mathrm{BRT}^{2}$ and $\left.\mathrm{IoD}^{3}\right)$, industry representatives (like Paul Polman ${ }^{4}$ and Feike Sijbesma ${ }^{5}$ ), investors (like Vanguard, Blackrock, ${ }^{6}$ Warren Buffett and Jamie Dimon $^{7}$ ), insurance companies (like Zurich ${ }^{8}$ ), central bank representatives (like Andy Haldane, ${ }^{9}$ Frank Elderson $^{10}$ and Christine Lagarde ${ }^{11}$ ), international policymakers (like Joe Biden and Ursula von der Leyen) and legal scholars $^{12}$ are arguing that both states and corporate actors have a role to play when it comes to fostering environmentally and socially sustainable business strategies and operations around the globe. The search for adequate responses to such scrutiny is reflected in developments in the societal, political and academic

1. World Economic Forum, 2020, 'The Universal Purpose of a Company in the Fourth Industrial Revolution' at weforum.org/agenda/2019/12/ davos-manifesto-2020-the-universal-purpose-of-a-company-in-thefourth-industrial-revolution.

2. Business Roundtable, 2020, 'Statement on the Purpose of a Corporation' at opportunity.businessroundtable.org/ourcommitment.

3. UK Institute of Directors, 2020, 'IoD Manifesto Corporate Governance' at iod.com/Portals/0/PDFs/Campaigns $\% 20$ and \%20Reports/Corporate \%20Governance/loD\%20Manifesto\%20-\%20Corporate \%20Governance.pdf?ver=2019-11-19-082215-783.

4. B. Ryder, 'The Parable of St Paul', The Economist 31 August 2017, economist.com/business/2017/08/31/the-parable-of-st-paul.

5. 'Ik wil geen dominee zijn, ik wil verleiden', NRC 10 January 2020, nrc.nl/nieuws/2020/01/10/ik-wil-geen-dominee-zijn-ik-wil-verleidena3986437.

6. L. Fink, 2020, 'A Fundamental Reshaping of Finance' at blackrock.com/ corporate/investor-relations/larry-fink-ceo-letter.

7. J. Dimon and W.E. Buffett, 'Short-termism is Harming the Economy', WSJ 6 June 2018, wsj.com/articles/short-termism-is-harming-theeconomy-1528336801.

8. 'Climate Issues are Top Global Concerns', Zurich 29 August 2016, zurichna.com/knowledge/articles/2016/08/climate-issues-are-topglobal-concerns.

9. A.G. Haldane, 'Who Owns a Company?', speech at University of Edinburgh Corporate Finance Conference 22 May 2015, hrmaturity.com/ wp-content/uploads/2015/08/BoE-speech-Who-owns-a-company.pdf.

10. F. Elderson, 'A Green Light to Lead Us on the Path of Economic Recovery', contribution to Petersberg Climate Dialogue side event Financing Climate Ambition in the context of COVID-19, 29 April 2020, bis.org/ review/r200529b.htm.

11. 'Banks Must Step up Climate Risk Disclosures, Lagarde Says', Reuters 27 February 2020, reuters.com/article/us-climatechange-ecb-lagardeidUSKCN2OL190.

12. See US law firm Lipton, Wachtell, Rosen and Katz statement at corpgov.law.harvard.edu/2017/09/01/corporate-governance-the-newparadigm- 2 and a proposal by 25 Dutch company law specialists at eur.nl/esl/nieuws/hoogleraren-ondernemingsrecht-bepleiten-deversterking-van-de-maatschappelijke-inbedding-van. 
debate on three separate but interrelated concepts: corporate social responsibility (CSR), business and human rights $(\mathrm{BHR})$ and responsible business conduct (RBC).

Post-World War II business scholarship adopted CSR to reflect on societal responsibilities of corporations, focusing on the responsibility of corporate actors for their impact on society, with an emphasis on self-guided decision-making by companies rather than government regulation on the issues involved. ${ }^{13}$ The focus presented by CSR was mostly on national impacts, compliance with the law and positive impacts ('doing good'), and much less so on international impacts, moving beyond compliance and/or negative impacts ('doing no harm'). However, the understanding of what CSR is and what it requires has shifted, as illustrated by a shift in the EC's definition of CSR from 'a concept whereby companies integrate social and environmental concerns in their business operations and in their interaction with their stakeholders on a voluntary basis' in $2001^{14}$ to 'the responsibility of enterprises for their impacts on society' with a supporting role for public authorities 'through a smart mix of voluntary policy measures and, where necessary, complementary regulation' in $2011 .{ }^{15}$ On the EC's website, CSR is currently characterised as a duty for companies to

understand their positive and negative impacts on society and the environment, [a]nd, therefore, [to] prevent, manage and mitigate any negative impact that they may cause, including within their global supply chain. ${ }^{16}$

These changes in the discourse on CSR can largely be explained by the significant developments that have taken place in the separate but related discourse on BHR. Originally primarily concerned with BHR impacts of multinational enterprises (MNEs) on human rights in host countries, increasing numbers of lawsuits before Western society courts from the mid-1990s onwards saw attention focused on corporate accountability for human rights-related harm and access to remedies for the victims of such harms in MNEs' home countries. ${ }^{17}$

The appointment in 2005 of John Ruggie as the UN Secretary-General's Special Representative on human rights and transnational corporations and other business enterprises ${ }^{18}$ led to the development of the 2008 'Pro-

13. See, in more detail, for example: A. Ramasastry, 'Corporate Social Responsibility Versus Business and Human Rights: Bridging the Gap between Responsibility and Accountability', 14/2 Journal of Human Rights 237 (2015) at 238-40.

14. EC, 'Promoting a European Network for Corporate Social Responsibility', $\operatorname{COM}(2001) 0366$ (18 July 2001), p. 6.

15. EC, 'A Renewed Strategy 2011-2014 for Corporate Social Responsibility', $\operatorname{COM}(2011) 681$, pp. 6,7 .

16. Seeec.europa.eu/growth/industry/sustainability/corporate-socialresponsibility_en (last visited 23 November 2020)

17. See, in more detail, for example: Ramasastry (2015), above n. 13 at 240-3.

18. SG/A/934 (28 July 2005), on the basis of UN Commission on Human Rights resolution E/CN.4/RES/2005/69 (20 April 2005). tect, Respect and Remedy' policy framework regarding BHR $^{19}$ and the 2011 UN Guiding Principles on Business and Human Rights (UNGPs). ${ }^{20}$ The resulting authoritative and internationally widely supported soft law instrument delivers the message that both states and business enterprises have a role to play in the prevention and remedy of business-related human rights abuse. This created a new focus for the discourse on BHR, with states owing a duty to protect against human rights abuses, corporations bearing a responsibility to prevent, mitigate and/or redress the negative effects of operations pursued by or for them on third parties' human rights, and both playing a role in providing effective remedies for victims of business-related human rights abuse. The socio-legal impact of the UNGPs especially has proven profound and far-reaching, with its standards for state and business conduct increasingly finding their way also into other international legal and policy instruments, in some cases with an expanded range of protected interests, binding legal obligations and/or dedicated enforcement mechanisms.

This is true for instance for the OECD Guidelines for Multinational Enterprises (OECD Guidelines), ${ }^{21}$ which consist of guidelines for MNEs operating in or from the territories of OECD Member States with respect to a range of issues. Under the current (2011) version of the OECD Guidelines, MNEs are required to carry out due diligence in order to identify, prevent and mitigate adverse impacts - a concept derived from the UNGPs in relation to a variety of issues. These include not only human rights - along with workers' rights and industrial relations - but also the environment, bribery and corruption, disclosure and consumer interests. Furthermore, even though the OECD Guidelines are a soft law instrument just like the UNGPs, they are accompanied by a grievance mechanism. National Contact Points have been established in the OECD Member States and a number of adhering countries, which are tasked, among other things, with the resolution of issues between MNEs and third parties relating to the implementation of the OECD Guidelines in specific instances. $^{22}$

It is in the context of the OECD Guidelines that the concept of RBC has been developed, with a focus on the potential adverse impacts of business operations in the global value chains of MNEs. According to the OECD, RBC 'means above all complying with laws, such as those on respecting human rights, environmental protection, labour relations and financial accountability, even where these are poorly enforced', but also 'involves responding to societal expectations communicated by

19. 'Protect, Respect and Remedy: A Policy Framework for Business and Human Rights', A/HRC/8/5 (7 April 2008).

20. OHCHR, Guiding Principles on Business and Human Rights, HR/PUB/ 11/04, 2011. Originally annex to A/HRC/17/31 (21 March 2011), endorsed by the UN Human Rights Council in resolution 17/4 (16 June 2011).

21. OECD, OECD Guidelines for Multinational Enterprises, OECD Publishing 2011, dx.doi.org/10.1787/9789264115415-en.

22. See, in more detail, S. Van 't Foort, 'Due diligence and supply chain responsibilities in specific instances', Erasmus Law Review, 4 (2019). 
channels other than the law, e.g. inter-governmental organisations, within the workplace, by local communities and trade unions, or via the press'. ${ }^{23}$ In recent years, the OECD Working Party on Responsible Business Conduct has contributed to the discourse on RBC through a number of guidance documents aimed at helping business enterprises implement and understand due diligence for RBC as foreseen in the OECD Guidelines, as well as promoting a common understanding of the concept among governments and stakeholders. ${ }^{24}$

International instruments such as the UNGPs and the OECD Guidelines and the accompanying societal, political and academic debate have fostered the development of further regulatory instruments aimed at improving RBC in global value chains both by states and by market actors themselves, often in cooperation with civil society organisations. At the time of writing (October 2020), one of the most salient examples of (upcoming) public regulation is the expected proposal in 2021 by the European Commission of legislation on corporate due diligence and on director's duties, as part of the Commission's work on sustainable corporate governance. $^{25}$ This is by no means the only relevant development at the EU level; a recent stocktaking shows that over the past decade there has been EU activity aimed at furthering CSR, BHR and RBC on multiple fronts. This includes, among other things, the introduction of regulation aimed at responsible sourcing in a number of specific sectors (timber, minerals and diamonds), the introduction of mandatory disclosure of non-financial and diversity information by certain large public interest companies, and the inclusion in recent trade and investment agreements of specific provisions committing the parties to promote CSR/RBC. ${ }^{26}$

At the same time, in a growing number of European countries regulatory instruments have been adopted that go beyond what is currently required of Europe-based companies on the basis of international or EU law and

23. See, for instance: OECD, 'Policy Framework for Investment User's Toolkit, Chapter 7: Promoting Responsible Business Conduct', 2011, p. 2, oecd.org/investment/toolkit/policyareas/responsiblebusinessconduct/ 42267935.pdf. It is added that: 'Private voluntary initiatives addressing this latter aspect of RBC are often referred to as corporate social responsibility (CSR)' (p. 2). Note however that views on the relationship between CSR and RBC differ; the EU, for instance, considers the concepts to mean the same and uses them interchangeably. See European Commission, 'Corporate Social Responsibility, Responsible Business Conduct, and Business \& Human Rights - Overview of Progress', March 2019, ec.europa.eu/transparency/regexpert/index.cfm? do=groupDetail. groupMeetingDoc\&docid $=34866$.

24. See, for instance: OECD, 'OECD Due Diligence Guidance for Responsible Business Conduct', 2018, mneguidelines.oecd.org/OECD-DueDiligence-Guidance-for-Responsible-Business-Conduct.pdf. See also p. 11 of said report with further references to several sector-specific instruments for, amongst others, the minerals, agriculture and garment and footwear supply chains and the extractives and financial sectors.

25. Business \& Human Rights Resource Center, 'EU Commissioner for Justice Commits to Legislation on Mandatory Due Diligence for Companies' (30 April 2020), business-humanrights.org/en/latest-news/eucommissioner-for-justice-commits-to-legislation-on-mandatory-duediligence-for-companies.

26. See, for an overview: European Commission, above n. 23. policy. Examples include the 2015 UK Modern Slavery Act, which introduces a reporting obligation specifically with respect to labour exploitation in the production chain, ${ }^{27}$ and the 2013 Swiss Loi fédérale sur les prestations de sécurité privées fournies à l'étranger, which introduces an obligation specifically for private military and security companies to prevent participation in armed conflicts abroad. ${ }^{28}$ The 2017 French Loi relative au devoir de vigilance des sociétés mères et des entreprises donneuses d'ordre introduces a broad obligation for large French companies to implement a due diligence plan to prevent adverse human rights and environmental impacts, also by subsidiaries and subcontractors. ${ }^{29}$ The 2019 Dutch Wet Zorgplicht Kinderarbeid features a similar obligation, but with a focus on child labour in the supply chain, specifically. ${ }^{30}$

The developments described here show how the developing societal, political and academic debates on the interrelated concepts of CSR, BHR and RBC have prompted major legal and policy developments over the past decade. The result is a comprehensive policy framework relating to RBC in global value chains and sustainable development more generally, which goes beyond 'do no harm' and is accompanied by an expanding catalogue of behavioural standards for both state and corporate actors. While its main focus is on the role of corporations in both home and host states, it draws states in as ultimate guarantors of the standards set out for responsible business behaviour, and deals with specific legal challenges in this context, like the issues related to the operations of MNEs as corporate groups ${ }^{31}$ and those related to extraterritoriality, ${ }^{32}$ in innovative ways. Meanwhile, these shifts in the debate on business regulation relating to human and environmental impacts in global value chains and accompanying legal developments are also increasingly informing debates on other types of impacts related to corporate governance, like sustainability and social inequality issues in the areas of company law, reporting and finance. ${ }^{33}$ Examples include the European Green Deal agenda, ${ }^{34}$ the EU debate on

27. Modern Slavery Act 2015, legislation.gov.uk/ukpga/2015/30/contents/ enacted, section 54

28. 935.41 Loi fédérale du 27 septembre 2013 sur les prestations de sécurité privées fournies à l'étranger, admin.ch/opc/fr/classified-compilation/ 20122320/index.html

29. Loi $n^{\circ}$ 2017-399 du 27 mars 2017 relative au devoir de vigilance des sociétés mères et des entreprises donneuses d'ordre, legifrance.gouv.fr/ jorf/id/JORFTEXT000034290626.

30. Wet van 24 oktober 2019 houdende de invoering van een zorgplicht ter voorkoming van de levering van goederen en diensten die met behulp van kinderarbeid tot stand zijn gekomen (Wet zorgplicht kinderarbeid), zoek.officielebekendmakingen.nl/stb-2019-401.html.

31. See L. Anker-Sørensen, 'Financial Engineering as an Alternative Veil for the Corporate Group', 13/5 European Company Law 158 (2016); J.G. Ruggie, 'Multinationals as Global Institution: Power, Authority and Relative Autonomy', 12/3 Regulation \& Governance 317 (2018)

32. See, for instance: L. Roorda, Jurisdiction Over Foreign Direct Liability Claims Against Transnational Corporations in EU Member States (2019).

33. See J. Veldman, P. Morrow \& F. Gregor, Corporate Governance for a Changing World: Final Report of a Global Roundtable Series (2016).

34. Seeec.europa.eu/info/strategy/priorities-2019-2024/european-greendeal_en (last visited 25 November 2020). 
directors' duties, ${ }^{35}$ the role of 'double materiality' in reporting standards ${ }^{36}$ and the $\mathrm{EU}$ sustainable finance initiative. $^{37}$

However, despite the comprehensive nature of these contemporary developments, many questions remain, notably with regard to the most effective ways to implement such a broad international policy framework and accompanying behavioural standards into laws and policies at the state level, and more specifically with regard to the coherence between the implementation in European Member States and the ambitions at the EU level. It is here that the potential lies for further academic research in this context, especially comparative and/or multi-perspective legal and policy research.

\section{Background and Set-up of the Special Issue}

To address these issues of policy coherence, the focus in this Special Issue will be on identifying relevant issues and developments as regards law and policy in the Netherlands relating to RBC in global value chains. The aim is to provide a multi-perspective view on relevant legal and policy issues and development, with a focus on gaps and/or best practices. In doing so, the Special Issue builds on the outcomes of a workshop on sustainable trade and development in the Dutch legal and policy framework, which was organised by the Erasmus School of Law in March 2018 in connection to the recently concluded SMART Horizon2020 project. ${ }^{38}$ In this workshop, relevant rules, case law and policies in various fields of Dutch law were evaluated in the light of relevant international policy frameworks like the UN Sustainable Development Goals, the OECD Guidelines and the UNGPs, and of relevant developments in other Western societies.

As will become clear from the contributions to this Special Issue, the past few years have seen the adoption of a number of legal instruments as well as a number of other legally relevant developments in the Netherlands

35. See EC Sustainable Corporate Governance Consultation, ec.europa.eu/ info/law/better-regulation/have-your-say/initiatives/12548-

Sustainable-corporate-governance (last visited 15 December 2020); the EU Study on due diligence requirements through the supply chain, op.europa.eu/en/publication-detail/-/publication/ 8ba0a8fd-4c83-11ea-b8b7-01aa75ed71a1/language-en.

36. Seeec.europa.eu/info/business-economy-euro/company-reporting-andauditing/company-reporting/non-financial-reporting_en.

37. Seeec.europa.eu/info/business-economy-euro/banking-and-finance/ sustainable-finance_en.

38. The Sustainable Market Actors for Responsible Trade (SMART) Horizon2020 project was aimed at promoting sustainable development within the planetary boundaries through academic legal research. In doing so, its focus was on 1) identifying the degree of policy coherence between the EU and its member states with regard to relevant rules and regulations related to trade, investment, corporate governance, etc.; and 2) determining whether and how this coherence is reflected in the implementation of those rules by companies, both at home and throughout their global value chains. See for an overview of the reform proposals resulting from the project: smart.uio.no/reform_proposals. relating to $\mathrm{RBC}$ in global value chains. These include the realisation since 2016 of International Responsible Business Conduct Agreements in eleven sectors of Dutch industry $\left(\right.$ Scheltema $\left.^{39}\right)$ and the adoption in 2019 of the Dutch Child Labour Due Diligence Act (Ennek$\left.\mathrm{ing}^{40}\right)$. Another relevant development is the presentation in 2019 by the Dutch government of a new model text for bilateral investment treaties that seeks to contribute to the sustainability and inclusivity of future Dutch trade and investment policy (Arcuri and Verbeek ${ }^{41}$ ). Meanwhile, in the field of Dutch company law, one can discern a more gradual development towards a comprehensive system comprising soft and hard law institutions that enhances the possibilities for safeguarding stakeholders' interests and sustainability. Recently, a number of developments have taken place that aim to expand on these possibilities (Lokin and Veldman ${ }^{42}$ ).

The developments mentioned do not only pertain to legal and policy instruments adopted with a view to promoting RBC in global value chains. They also pertain to ex post facto dispute resolution between third parties that have been detrimentally affected by irresponsible business conduct in this context and the companies involved. Highly relevant in this respect are the recent judgements in a number of civil and criminal liability cases that have been brought before Dutch courts against Netherlands-based internationally operating business enterprises in relation to human rights-related or environmental harm caused in host countries (Enneking $^{43}$ ). The same is true for the decisions rendered by the Dutch National Contact Point in relation to complaints filed over alleged violations by Dutch companies of the norms set out in the OECD Guidelines (Van ' $t$ Foort $^{44}$ ).

At the same time, the potential of ex post dispute resolution when it comes to realising responsible business behaviour by companies and industries is limited and arguably requires ex-ante regulatory interventions to play at least a supporting role. The detrimental consequences for people and the environment that may ensue if such interventions fail to materialise can be illustrated by case studies relating to two Netherlands-based companies in the global waste industry (Van Wingerde and Bisschop ${ }^{45}$ ). At the same time, regulatory interventions to promote RBC in global value chains may be targeted

39. See M. Scheltema, 'The Dutch International Responsible Business Conduct Agreements: Effective Initiatives?', Erasmus Law Review, 4 (2019).

40. See L. Enneking, 'Putting the Dutch Child Labour Due Diligence Act into Perspective', Erasmus Law Review, 4 (2019).

41. See A. Arcuri and B.J. Verbeek, 'The New Dutch Model Investment Agreement: On the Road to Sustainability or Keeping up Appearances?, Erasmus Law Review, 4 (2019).

42. See M. Lokin and J. Veldman, 'The Potential of the Dutch Corporate Governance Model for Sustainable Governance and Long Term Stakeholder Value', Erasmus Law Review, 4 (2019).

43. See L. Enneking, 'Putting the Dutch Child Labour Due Diligence Act into Perspective', Erasmus Law Review, 4 (2019).

44. See S. Van 't Foort, 'Due diligence and supply chain responsibilities in specific instances', Erasmus Law Review, 4 (2019).

45. See K. Van Wingerde and L. Bisschop, 'Waste Away. Examining Systemic Drivers of Global Waste Trafficking Based on a Comparative Analysis of Two Dutch Cases', Erasmus Law Review, 4 (2019). 
not only at the companies involved, but in some cases also at consumers, shifting (part of) the responsibility to avoid business-related harm to people and the environment to them. The role of consumers in promoting the production of renewable energy sources is a case in point, thus warranting an analysis of the potential of Dutch energy law and policy in getting Dutch consumers to participate in the energy transition $\left(\right.$ Cseres $\left.^{46}\right)$.

The contributions in this Special Issue identify relevant developments and institutions in the Netherlands, including rules and regulations related to trade, investment and corporate governance as well as cases related to corporate and consumer responsibilities, and assess their role in relation to the potential to provide a positive response to the concern about the human and environmental impacts of business activities. Together, they provide a multi-perspective view of relevant gaps and/or best practices with regard to regulatory governance in the Netherlands while at the same time enabling a comparative debate on the extent to which these diverse developments and institutions are in line with stated policy goals in this context both at national and EU levels. In doing so, this Special Issue aims to contribute to further coherence between national and EU policies with regard to RBC in global value chains and sustainable development. This topic will be addressed in concluding reflections from the perspective of the aforementioned SMART project (Sjåfjell $\left.{ }^{47}\right)$.

47. See B. Sjåfjell, 'Towards policy coherence for sustainable business', Erasmus Law Review, 4 (2019). 